\title{
Viridibacillus Soli sp.nov., Isolated from Forest Soil in Ailaoshan National Nature ReserveViridibacillus Soli sp.nov., Isolated from Forest soil in Ailaoshan National Nature Reserve
}

\author{
Yan Xu \\ Yunnan Institute of Microbiology \\ Jiang-Yuan Zhao \\ Yunnan Institute of Microbiology \\ Yu Geng \\ Yunnan Institute of Microbiology \\ Hui-Ren Yuan \\ Yunnan Institute of Microbiology \\ Le-Le Li \\ Yunnan Institute of Microbiology \\ Meng-Liang Wen \\ Yunnan Institute of Microbiology \\ Ming-Gang Li \\ Yunnan Institute of Microbiology
}

Shu-Kun Tang ( $\nabla$ tangshukun@ynu.edu.cn )

Yunnan Institute of Microbiology, Yunnan University https://orcid.org/0000-0001-9141-6244

\section{Research Article}

Keywords: Viridibacillus sp. nov. , Forest soil , Genome analysis , Polyphasic taxonomy

Posted Date: September 1st, 2021

DOI: https://doi.org/10.21203/rs.3.rs-851767/v1

License: (c) (i) This work is licensed under a Creative Commons Attribution 4.0 International License. Read Full License 


\section{Abstract}

A Gram-staining positive, rod-shaped, and subterminal endospore-forming bacterium, designated strain YIM B01967 ${ }^{\top}$, was isolated from a forest soil sample collected in Ailaoshan National Nature Reserve, Yuxi City, Xinpin county, Yunnan province, China. Strain YIM B01967 ${ }^{\top}$ showed the highest 16 S rRNA gene sequence similarity with Viridibacillus arvi (99.1\%) and Viridibacillus arenosi (98.9\%). Based on the phylogenetic and 16S rRNA gene sequence results, strain YIM B01967 ${ }^{\top}$ was affiliated to the genus Viridibacillus. The growth of YIM B01967 ${ }^{\top}$ was observed at $15-35^{\circ} \mathrm{C}$ (optimum, $28^{\circ} \mathrm{C}$ ), pH 7.0-9.0 (optimum, $\mathrm{pH} 7.5$ ) and in the presence of $0-2 \%(\mathrm{w} / \mathrm{v}) \mathrm{NaCl}$ (optimum in $2 \% \mathrm{NaCl}$ ). The cell-wall sugars include ribose, glucose, arabinose, galactose, and mannose. The quinone system consisted of the major compound MK-8 and moderate amounts of MK-7. The major fatty acids $(>10 \%)$ were iso- $\mathrm{C}_{15: 0}$, anteiso-

$\mathrm{C}_{15: 0}, \mathrm{C}_{16: 1} \omega 10 \mathrm{c}$. The major polar lipids profile included DPG, PME. The cell wall peptidoglycan was most likely of the type A4a with an L-Lys-D-Asp interpeptide bridge. The genomic DNA G + C content of strain YIM B01967 ${ }^{\top}$ was $36.3 \mathrm{~mol} \%$. The ANI and dDDH values between strain YIM B01967 and the two reference strains Viridibacillus arvi DSM $16317^{\top}$ and Viridibacillus arenosi DSM $16319^{\top}$ are $61.0 \%$ and $32.1 \%, 60.0 \%$ and $33.1 \%$ based on the draft genome sequence. The results support the conclusion that strain YIM B01967 ${ }^{\top}$ represents a novel species of the genus Viridibacillus, the for which the name Viridibacillus soli sp. Nov., is proposed. The type strain is $\mathrm{YIM} \mathrm{B01967}^{\top}\left(=\mathrm{KCTC} 43249^{\top}=\mathrm{CGMCC}\right.$ $\left.1.18436^{\top}\right)$.

\section{Introduction}

The genus Viridibacillus belongs to the family Planococcaceae, phylum Bacillales which was first proposed by Albert et al. (2007) to reclassify 3 species in the genus Bacillus. To date, this genus consists of 3 species, namely Viridibacillus arenosi (Heyrman et al.2005; Albert et al.2007), Viridibacillus arvi (Heyrman et al. 2005; Albert et al.2007), and Viridibacillus neidei (Nakamura et al. 2002; Albert et al.2007), all isolated from soil. In July 2019, we isolated the strain YIM B01967 ${ }^{\top}$ from a forest soil sample in Ailaoshan National Nature Reserve, Yuxi City, Xinpin county, Yunnan province, China. Through the study of polyphasic taxonomy, strain YIM B01967 ${ }^{\top}$ is considered to be a new member of the genus Viridibacillus, named Viridibacillus soli sp.nov.

\section{Methods And Materials}

\section{Strain isolation and culture conditions}

Forest soil samples were collected from the Ailao Mountain National Nature Reserve in Yuxi City, Yunnan Province, China. Isolation was performed by the standard dilution plate method on plate count agar (PCA; Difco) at $28^{\circ} \mathrm{C}$ for $4-7$ days. The isolation procedure was performed as described by Liu et al. (2017). The pure culture of the randomly selected single colony strain YIM B01967T was stored on a PCA slant at $4^{\circ} \mathrm{C}$, and stored as a glycerol suspension $(20 \%, \mathrm{w} / \mathrm{v})$ at $-80^{\circ} \mathrm{C}$. Besides, it was preserved in lyophilized form in 
skimmed milk at $4{ }^{\circ} \mathrm{C}$ temperature. The reference strain, Viridibacillus arvi DSM $16317^{\top}$ was obtained from the Deutsche Sammlung von Mikroorganismen und Zellkulturen (DSMZ).

\section{Phylogenetic and genotypic analysis}

The preliminary identification of strain YIM B01967 ${ }^{\top}$ was performed based on the $16 \mathrm{~S}$ rRNA gene sequence and phylogenetic analysis. The extraction of genomic DNA, PCR amplifcation andsequencing of the 16S rRNA gene were carried out as described by Li et al. (2007). The 16S rRNA gene sequence was compared at the EZBioCloud server (https: //www. ezbio cloud. net; Yoon et al. 2017). Multiple sequence alignments were performed with CLUSTAL_X (Thompson et al.1997). Phylogenetic analysis was performed using the MEGA software package version 7.0 (Kumar et al. 2016). The phylogenetic trees were reconstructed using neighbor-joining (NJ) (Saitou and Nei 1987), maximum-likelihood (ML) (Felsenstein 1981), and maximum-parsimony (MP) (Fitch 1971) with MEGA 7 software (Kumar et al. 2016). The method used to compute evolutionary distances was Kimura's two-parameter (Kimura 1980). The stability of the topology and the phylogenetic tree was evaluated by using bootstrap analysis (Felsenstein 1985), with 1000 replications. The 16S rRNA gene sequence of Bhargavaea cecembensis DSM $22132^{\top}$ was used as an outgroup.

The sequencing of the whole genome was performed on the HiSeq X-Ten platform (Illumina). The draft whole-genome sequencing of the strain YIM B01967 ${ }^{\top}$ was performed by Majorbio (Shanghai, China). ANlb values were calculated using JSpeciesWS (http://jspecies. ribohost.com/jspeciesws/\#analyse) (Richter et al. 2016). The Genome-to-Genome Distance Calculator, version 2.1 was used to calculate the digital DNA-DNA hybridization (dDDH) value (Meier-Kolthoff et al.2013). The dDDH results of

recommended formula 2 (identities/HSP length) were used. A phylogenomic tree was constructed based on genomic data using the supermatrix method (Zhi et al.2017).

\section{Morphological, physiological, and biochemical analyses}

To determine the differential phenotypic properties, strain YIM B01967 ${ }^{\top}$ was subjected to morphological, physiological, and biochemical analyses. Phenotypic characteristics of strain YIM B01967 ${ }^{\top}$ were observed using cells grown on PCA medium for 4 days at $28^{\circ} \mathrm{C}$. Cell morphology was examined using a transmission electron microscope (JEM 2100; JEOL). For transmission electron microscopy, cells were negatively stained with $1 \%$ phosphotungstic acid before observation. Colony morphology and pigmentation were observed on PCA medium incubated at $28^{\circ} \mathrm{C}$ for 4 days. Growth at different temperatures $\left(4,10,15,20,25,28,30,35,37,40\right.$, and $\left.45^{\circ} \mathrm{C}\right)$ was examined after incubation on PCA medium for 4 days. Tolerance to $\mathrm{NaCl}$ between 0 and $10 \%(\mathrm{w} / \mathrm{v}$, at intervals of $2 \%$ ) in plate count broth (PCB; Difco) medium at $28{ }^{\circ} \mathrm{C}$ was recorded after 4 days. The ability of the strain to grow at different $\mathrm{pH}$ values (4.0-10.0, at 0.5 intervals by using the buffer system described by Tang et al. 2010). Catalase activity was determined by the production of bubbles after adding $3 \% \mathrm{H}_{2} \mathrm{O}_{2}$ to the tested bacteria 
(Tarrand and Gröschel 1982). Enzyme activities, production of acid, utilization of different compounds, and the other physiological functions were tested with API ZYM, API 20NE kits (bioMérieux), API 50CHB kits, and the Biolog GEN III MicroPlates kits according to the manufacturers' instructions. All tests were completed in duplicate.

\section{Chemotaxonomic characterization}

The isolation of the peptidoglycan and analysis of the peptidoglycan structure were done according to published protocols (Schumann 2011; Schleifer and Kandler 1972). Analyses of diaminopimelic acid in the cell wall and sugars of whole-cell hydrolysates were performed according to the procedures described by Lechevalier and Lechevalier (1970) and Tang et al. (2009). Cellular fatty acids were extracted, methylated, and analyzed by using the Sherlock Microbial Identification System (MIDI) according to the manufacturer's instructions. Fatty acid methyl esters were analyzed by using the Microbial Identification Software Package (Sherlock Version 6.1; MIDI databaseTSBA6) (Sasser 1990). The respiratory quinones of YIM B01967 ${ }^{\top}$ were extracted from lyophilized cells (Collins et al. 1977), purified by TLC, and then analyzed by HPLC according to the methods of Xie and Yokota (2003). Polar lipids were extracted, examined by two-dimensional TLC, and identified using the procedures described by Collins and Jones (1980) and Minnikin et al. (1979).

\section{Results And Discussion}

\section{Molecular phylogenetic analysis}

The almost-complete 16S rRNA gene sequence of YIM B01967 was 1540 bp (GenBank accession number MW386301). Strain YIM B01967 ${ }^{\top}$ showed the highest 16S rRNA gene sequence similarity with Viridibacillus arvi (99.05\%) and Viridibacillus arenosi (98.92\%). The NJ tree, MP tree, and ML tree for the 16S rRNA shared the same topology and were presented in Fig 1, Fig S1, and Fig S2, respectively.

The draft genome of strain YIM B01967 ${ }^{\top}$ contained 112 contigs, with a total length of 4,553,251 bp and an N50 length of 171,059 bp (GenBank accession number JAEOAH000000000), and genome coverage of 14.0'. The DNA G+C content of strain YIM B01967 ${ }^{\top}$ was determined from the genome to be $36.3 \mathrm{~mol} \%$. Strain YIM B01967 $7^{\top}$ genome was annotated with 4,444 genes, included 4,200 protein-coding genes, 60 rRNA genes, 50 tRNA genes, 5 ncRNA genes, and 184 pseudogenes. In contrast, the draft genome of the reference strain Viridibacillus arvi DSM $16317^{\top}$ consists of 4,758,570 bp with an N50 contig length of $244,670 \mathrm{bp}$ and a G+C content of $35.0 \mathrm{~mol} \%$. The ANI value between strain YIM B01967 ${ }^{\top}$ and Viridibacillus arvi DSM $16317^{\top}$ was $61.03 \%$ based on the draft genome sequence, which was lower than the $95.0 \%$ cut-off for species demarcation (Richter et al. 2016). The DNA-DNA hybridization values between strain YIM B01967 ${ }^{\top}$ and Viridibacillus arvi DSM $16317^{\top}$ was $32.1 \%$, which was much lower than 
the threshold value (70\%) recommended for distinguishing novel prokaryotic species (Chun et al. 2018). The phylogenomics tree of YIM B01967 ${ }^{\top}$ with the closely related strains was presented in Fig 2.

\section{Morphological, physiological, and biochemical analyses}

The YIM B01967 ${ }^{\top}$ strain was Gram-positive, sporulating and active rod-shaped. The endospores were approximately round and are located in the sporangia with enlarged or slightly enlarged ends. (Fig S1). Cells can grow at $\mathrm{pH}$ 6.0-9.0 (optimum, $\mathrm{pH} 7.5$ ) and in the presence of $0-2 \%(\mathrm{w} / \mathrm{v}) \mathrm{NaCl}$ (optimum in $2 \%$ $\mathrm{NaCl}$ ), Other physiological characteristics are given in Table 1. Strain YIM B01967 ${ }^{\top}$ was Catalase-positive and oxidase-negative, and this feature was also present in Viridibacillus arvi DSM $16317^{\top}$ and Viridibacillus arenosi DSM $16319^{\top}$.

\section{Table 1}

Phenotypic and chemotaxonomic characteristics that differentiate strain YIM B01967 ${ }^{\top}$ from closely related reference strains 


\begin{tabular}{|c|c|c|c|}
\hline Characteristic & 1 & 2 & 3 \\
\hline Colony colour & Light yellow & White & White \\
\hline \multicolumn{4}{|l|}{ Growth conditions } \\
\hline Temperature $\left({ }^{\circ} \mathrm{C}\right)$ & $15-37$ & $5-40$ & $5-37$ \\
\hline Growth in $5 \% \mathrm{NaCl}$ & - & - & + \\
\hline Anaerobic growth & w & $w$ & - \\
\hline \multicolumn{4}{|l|}{ API 20NE } \\
\hline Urease & + & + & - \\
\hline$\beta$-Glucosidase & + & - & - \\
\hline Malic acid & + & - & - \\
\hline Nitrate reduced & + & - & + \\
\hline Gelatin hydrolysis & + & - & + \\
\hline Aesculin hydrolysis & + & - & - \\
\hline $\begin{array}{l}\text { Arginine double } \\
\text { hydrolysis }\end{array}$ & + & w & $N$ \\
\hline ONPG & - & w & - \\
\hline \multicolumn{4}{|l|}{ API ZYM } \\
\hline Casein hydrolysis & - & w & - \\
\hline Esterase & + & - & $\mathrm{N}$ \\
\hline Lipid esterase & + & - & $\mathrm{N}$ \\
\hline Chymotrypsin & - & + & $\mathrm{N}$ \\
\hline$\beta$-Galactosidase & - & + & $\mathrm{N}$ \\
\hline \multicolumn{4}{|l|}{$\begin{array}{l}\text { Acid production } \\
\text { from(50CHB) }\end{array}$} \\
\hline $\mathrm{N}$-acetylglucosamine & - & w & - \\
\hline D-fructose & - & + & - \\
\hline Myo-inositol & + & - & - \\
\hline D-arabitol & + & - & - \\
\hline $\begin{array}{l}\text { DNA G + C content } \\
(\mathrm{mol} \%)\end{array}$ & 36.3 & 35.0 & 35.0 \\
\hline Polar lipids & DPG, PME, PG, PE, 2PL & DPG, PG, PE, APL, & DPG, PG, PE, APL, \\
\hline
\end{tabular}




$\begin{array}{llll} & & 2 \mathrm{PL} & 2 \mathrm{PL} \\ \text { Major fatty acids }(>10 \%) & \text { iso- } \mathrm{C}_{15: 0} \text {, anteiso- } \mathrm{C}_{15: 0}, & \text { iso- } \mathrm{C}_{15: 0}, \text { anteiso- } & \text { iso- } \mathrm{C}_{15: 0} \text {, anteiso- } \\ & \mathrm{C}_{16: 1} \omega 10 c & \mathrm{C}_{15: 0} & \mathrm{C}_{15: 0}\end{array}$

Strains: (1) YIM B01967'; (2) Viridibacillus arvi DSM $16317^{\top}$ (The data of API 20NE, API ZYM, acid production from (50CHB) and major fatty acids are from this research, other data from Heyrman et al. 2005; Albert et al. 2007); (3) Viridibacillus arenosi DSM $16319^{\top}$ (data from Heyrman et al. 2005; Albert et al. 2007).

+ Positive, - negative, w weak. All data were obtained from this study except where indicated.

\section{Chemotaxonomic characterization}

The cell wall amino acids of strain YIM B01967 contained aspartic acid, glutamic acid, alanine and lysine. As hese amino acids matches those of the reference strain Viridibacillus arvi DSM $16317^{\top}$, we deduce that the peptidoglycan was the type A4a (Schleifer and Kandler 1972) with an L-Lys-D-Asp interpeptide bridge (Fig S4). Ribose, glucose, arabinose, galactose, and mannose were the major wholecell sugars of strain. The quinone system consisted of the major compound MK-8 and moderate amounts of MK-7 in strain, which was identical to that found in members of the genus Viridibacillus (Albert et al. 2007). The cellular fatty acids profile consisted of iso- $\mathrm{C}_{15: 0}(34.64 \%)$, anteiso- $\mathrm{C}_{15: 0}(12.72 \%)$ and $\mathrm{C}_{16: 1} \omega 10 c(11.53 \%)$ as major fatty acids $(>10 \%)$, and $\mathrm{C}_{16: 1} \omega 7 \mathrm{c}$ alcohol $(8.95 \%)$, anteiso- $\mathrm{C}_{17: 0}(6.15 \%)$, iso$\mathrm{C}_{16: 0}(6.02 \%)$, Summed Feature 4(iso I- $\mathrm{C}_{17: 1} /$ anteiso B)(5.02\%), iso- $\mathrm{C}_{14: 0}(3.68 \%)$, iso- $\mathrm{C}_{17: 1} \omega 10 c(3.06 \%)$, iso- $\mathrm{C}_{17: 0}(2.94 \%)$ and $\mathrm{C}_{16: 0}(2.21 \%)$ as minor fatty acids(>1\%).(Table S1). The polar lipids of the strain YIM B01967 ${ }^{\top}$ were diphosphatidylglycerol (DPG), phosphatidylmethylethanolamine (PME), phosphatidylglycerol (PG), phosphatidylethanolamine (PE), and two unidentified phospholipids (PL1, PL2). (Fig S5). Chemotaxonomic analyses including cell-wall peptidoglycan, whole-cell fatty acids, cellwall sugars, and polar lipids exhibited the close similarity of strain YIM B01967 ${ }^{\top}$ to type strains of the closely related species, which confirmed its affiliation to the genus Viridibacillus, with sufficient differences to warrant its proposal as representing a novel species of the genus Viridibacillus.

The detailed differentiating phenotypic and chemotaxonomic characteristics features between YIM B01967 and the reference strains were given in Table 1.

Consequently, based on the above findings, we characterized strain YIM B01967 ${ }^{\top}$ as a novel species within the genus Viridibacillus, for which the name Viridibacillus soil sp.nov.is proposed.

\section{Description of Viridibacillus soli sp.nov.}




\section{Viridibacillus soli (so'li. L. neut. gen. $\mathrm{n}$. soli of soil, the source of the type strain)}

Cells are straight, round-ended, Gram-positive, motile rods (0.6-0.8×2.5-3.0 mm), occurring singly and in pairs, the endospores are approximately round and are located in the sporangia with enlarged or slightly enlarged ends. Growth occurs at temperature range of $15-37^{\circ} \mathrm{C}$ (optimum, $28^{\circ} \mathrm{C}$ ), pH 6.0-9.0 (optimum, $\mathrm{pH} 7.5)$ and in the presence of $0-2 \%(\mathrm{w} / \mathrm{v}) \mathrm{NaCl}$ (optimum $2 \% \mathrm{NaCl}$ ). Catalase-positive and oxidasenegative. In API 20NE, positive for urease, $\beta$-glucosidase, and malic acid, nitrate is reduced, gelatin is hydrolyzed. In API ZYM, positive for alkaline phosphatase, esterase, lipid esterase, leucine aramidase, valine Aramidase, acid phosphatase, and naphthol-AS-Bl-phosphohydrolase. In the Biolog GEN III MicroPlate, positive for $\mathrm{N}$-acetyl-d-glucosamine, $\mathrm{N}$-acetyl- $\beta$-d-mannosamine, $\mathrm{D}$-galactose, 3-methylglucose, inosine, D-mannitol, D-arabitol, myoinositol, glycerol, D-glucose-6- $\mathrm{PO}_{4}$, D-fructose-6- $\mathrm{PO}_{4}$, gelatin, L-alanine, L-arginine, L-glutamic acid, L-histidine, L-pyroglutamic acid, L-serine, D-galacturonic acid, Dgluconic acid, D-glucuronic acid, quinic acid, D-saccharic acid, D-lactic acid, methyl ester, L-lactic acid, aketo-glutaric acid, L-malic acid, Tween 40, $\alpha$-hydroxy-butyric acid, $\beta$-hydroxy-D, L-butyric acid, acetic acid, $1 \%$ sodium lactate, nalidixic acid, aztreonam. In the API $50 \mathrm{CHB}$ gallery, acid is not produced from any of the carbohydrate substrates. Cell wall peptidoglycan is presumably of the type A4a with an L-Lys-D-Asp interpeptide bridge. The cell-wall sugars are ribose, glucose, arabinose, galactose, and mannose. The quinone system consists of the major compound MK-8 and moderate amounts of MK-7. The fatty acids $\left(>5 \%\right.$ of total fatty acids) are iso- $\mathrm{C}_{15: 0 \text {, }}$ anteiso- $\mathrm{C}_{15: 0}, \mathrm{C}_{16: 1} \omega 10 c, \mathrm{C}_{16: 1} \omega 7 c$ alcohol, anteiso- $\mathrm{C}_{17: 0}$, iso- $\mathrm{C}_{16: 0}$. The polar lipids profile include diphosphatidylglycerol, phosphatidylglycerol, phosphatidylmethylethanolamine phosphatidylethanolamine, and moderate to minor amounts of two unknown phospholipids (PL1, PL2). The DNA G+C content of the type strain is $36.3 \mathrm{~mol} \%$ based on the draft genome sequence.

The type strain, YIM B01967 $\left(=\right.$ KCTC $43249^{\top}=$ CGMCC $1.18436^{\top}$ ), was isolated from a soil sample collected from a forest in Ailaoshan National Nature Reserve, Yuxi City, Xinpin county, Yunnan province, China.

The GenBank/EMBL/DDBJ accession number for the 16S rRNA gene sequence and the draft genome sequence are MW386301 and JAEOAH000000000 respectively.

\section{Abbreviations}

PCA Plate count agar

PCB Plate count broth

DPG Diphosphatidylglycerol 
PME Phosphatidylmethylethanolamine

PG Phosphatidylglycerol

PE Phosphatidylethanolamine

PL Unidentified phospholipid

\section{Declarations}

\section{Funding:}

This work was supported by the National Natural Science Foundation of China (31760019), Major Science and Technology Projects of Yunnan Province (Digitalization, development and application of biotic resource 202002AA100007), and Basic Research Project of Yunnan Province (202001BB050025).

\section{Conflict of interest:}

The authors declare that they have no conflicts of interest.

\section{References}

1. Albert R, Archambault J, Lempa M, Hurst B, Richardson C, Gruenloh S, Busse H (2007) Proposal of Viridibacillus gen. nov., and reclassification of Bacillus arvi, Bacillus arenosi and Bacillus neidei as Viridibacillus arvi gen. nov., comb. nov., Viridibacillus arenosi comb. nov., and Viridibacillus neidei comb. nov. Int J Syst Evol Microbiol 57 (12), 2729-2737.

2. Chun J, Oren A, Ventosa A, Christensen H, Arahal DR, et al(2018) Proposed minimal standards for the use of genome data for the taxonomy of prokaryotes. Int J Syst Evol Microbiol 68:461-466

3. Collins MD, Jones D (1980) Lipids in the classification and identification of coryneform bacteria containing peptidoglycans based on 2, 4-diaminobutyric acid. J Appl Bacteriol 48:459-470

4. Collins MD, Pirouz T, Goodfellow M, Minnikin DE (1977) Distribution of menaquinones in Actinomycetes and Corynebacteria. J Gen Appl Microbiol 100(2), 221-230.

5. Felsenstein J (1981) Evolutionary trees from DNA sequences: a maximum likelihood approach. J Mol Evol 17:368-376

6. Felsenstein J (1985) Confidence limits on phylogenies: an approach using the bootstrap. Evolution 39:783-791

7. Fitch WM (1971) Toward defining the course of evolution: minimum change for a specific tree topology. Syst Zool 20:406-416

8. Feng YZ, Chunyu WX, Liang R, Hahnke RL, Schumann P, Zhao YR, Gao S, Yin M, Ji Y, Sun L, Zhi, XY, \& Tang SK (2020) Vallicoccus soli gen. nov., sp. nov., a novel actinobacterium isolated from soil, and 
description of Vallicoccaceae fam. nov., Motilibacterales ord. nov. Antonie van Leeuwenhoek 113(12), 2155-2165.

9. Heyrman J (2005) Bacillus arenosi sp. nov., Bacillus arvi sp. nov., and Bacillus humi sp. nov., isolated from soil. Int J Syst Evol Microbiol 55 (1), 111-117.

10. Kimura M (1980) A simple method for estimating evolutionary rates of base substitutions through comparative studies of nucleotide sequences. J Mol Evol 16:111-120

11. Kroppenstedt RM (1985) Fatty acid and menaquinone analysis of actinomycetes and related organisms.In: Goodfellow M, Minnikin DE (eds) Chemical methods in bacterial systematics. Academic Press, London, pp 173-199

12. Kumar S, Stecher G, Tamura K (2016) MEGA7: molecular evolutionary genetics analysis version 7.0 for bigger datasets. Mol Biol Evol 33:1870-1874

13. Lechevalier MP, Lechevalier HA (1970) Chemical composition as a criterion in the classification of aerobic actinomycetes. Int J Syst Bacteriol 20:435-443

14. Liu CB, Jiang Y (2017) Diversity, antimicrobial activity, and biosynthetic potential of cultivable actinomycetes with lichen symbiosis. Microb Ecol 74:570-584

15. Li WJ, Xu P, Schumann P, Zhang YQ, Pukall R, Xu LH, Stackebrandt E, Jiang CL (2007) Georgenia ruanii sp. nov., a novel actinobacterium isolated from forest soil in Yunnan (China), and emended description of the genus Georgenia. Int J Syst Evol Microbiol 57:1424-1428

16. Minnikin DE, Collins MD, Goodfellow M (1979) Fatty acid and polar lipid composition in the classification of Cellulomonas, Oerskovia and related taxa. J Appl Bacteriol 47:87-95

17. Meier-Kolthoff JP, Auch AF, Klenk HP, Göker M (2013) Genome sequence-based species delimitation with confidence intervals and improved distance functions. BMC Bioinf Feb 21; 14: 60.

18. Nakamura LK, Shida O, Takagi H, \& Komagata K (2002) Bacillus pycnus sp. nov., and Bacillus neidei sp. nov., round-spored bacteria from soil. Int J Syst Evol Microbiol 52 (Pt 2), 501-505.

19. Richter M, Rosselló-Móra R, Oliver Glöckner F, Peplies J (2016) JSpeciesWS: a web server for prokaryotic species circumscription based on pairwise genome comparison. Bioinformatics (Oxford, England), 32(6), 929-931.

20. Sasser M (1990) Identification of bacteria by gas chromatography of cellular fatty acids.USFCC Newsl 20:16

21. Schleifer KH, Kandler O (1972) Peptidoglycan types of bacterial cell walls and their taxonomic implications. Bacteriol Rev 36:407-477

22. Saitou N, Nei M (1987) The neighbor-joining method: a new method for reconstructing phylogenetic trees. Mol Biol Evol 4:406-425

23. Schumann P (2011) Peptidoglcan structure. Methods Microbiol 38:101-129

24. Tang SK, Wang Y, Chen Y, Lou K, Cao LL, Xu LH, Li WJ (2009) Zhihengliuella alba sp. nov., and emended description of the genus Zhihengliuella. Int J Syst Evol Microbiol 59:2025-2032 
25. Tang SK, WangY ZH, Lee JC, Lou K, Kim CJ, Li WJ (2010) Haloechi-nothrix alba gen. nov., sp. nov., a halophilic, filamentous actinomycete of the suborder Pseudonocardineae. Int J Syst Evol Microbiol 60:2154-2158

26. Tarrand JJ, Gröschel DH (1982) Rapid, modified oxidase test for oxidase-variable bacterial isolates. J Clin Microbiol 16:772-774

27. Thompson JD (1997) The CLUSTAL_X windows interface: flexible strategies for multiple sequence alignment aided by quality analysis tools. Nucleic Acids Res 25(24), 4876-4882.

28. Xie CH, Yokota A (2003) Phylogenetic analyses of Lampropedia hya-lina based on the 16S rRNA gene sequence. J Gen Appl Microbiol 49:345-349

29. Xu P (2005) Naxibacter alkalitolerans gen. nov., sp. nov., a novel member of the family “Oxalobacteraceae" isolated from China. Int J Syst Evol Microbiol 55 (3), 1149-1153.

30. Yoon SH, Ha SM, Kwon S, Lim J, Kim Y, Seo H, \& Chun J (2017)Introducing EzBioCloud: a taxonomically united database of $16 \mathrm{~S}$ rRNA gene sequences and whole-genome assemblies. Int $\mathrm{J}$ Syst Evol Microbiol 67(5), 1613-1617.

31. Zhi XY, Jiang Z, Yang LL, Huang Y (2017) The underlying mechanisms of genetic innovation and speciation in the family Corynebacteriaceae: A phylogenomics approach. Mol Phylogenet Evol Feb;107: 246-255.

\section{Figures}

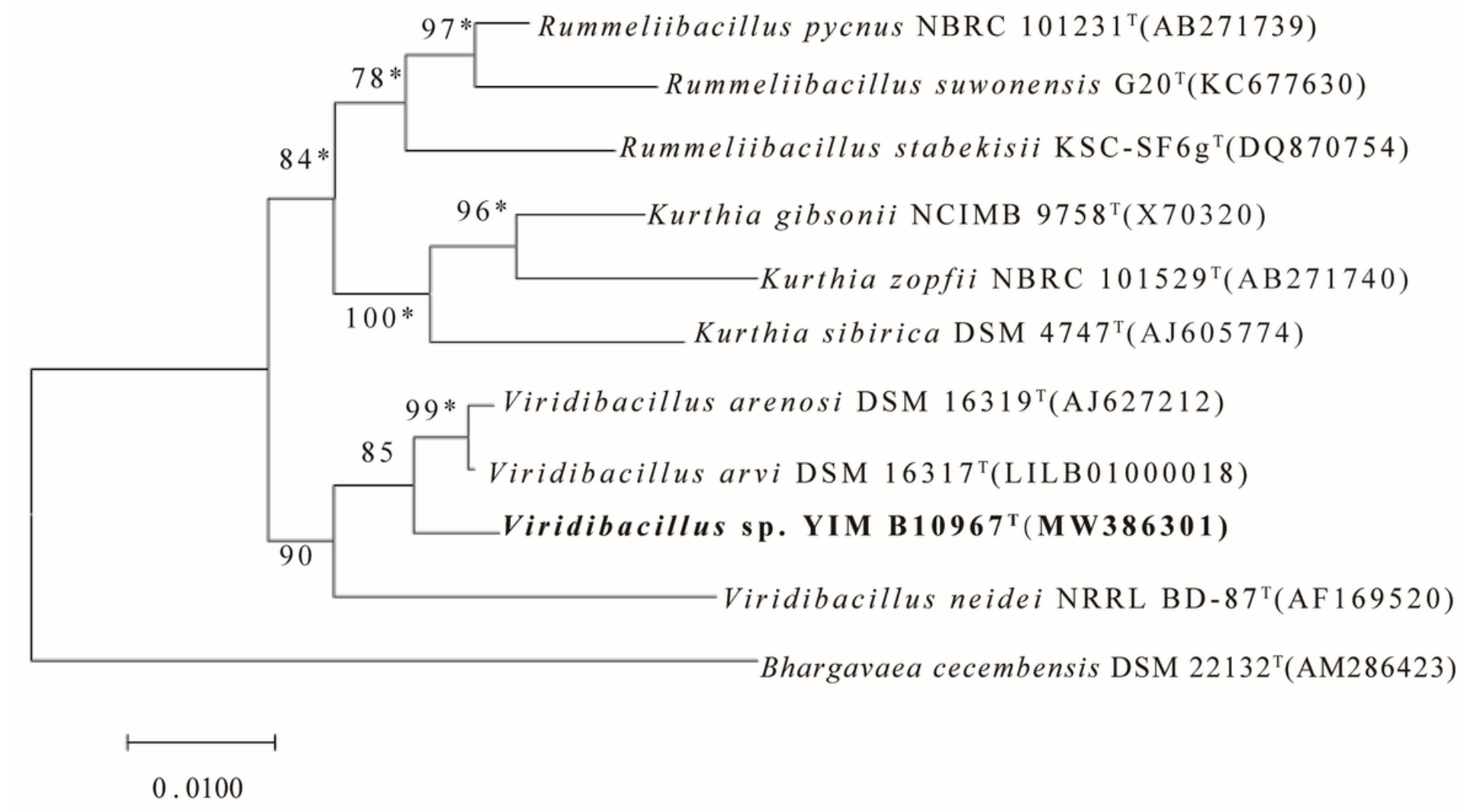




\section{Figure 1}

Neighbour-joining tree based on 16S rRNA gene sequences showing the relationships between strain YIM B01967T and some members of the family Planococcaceae. Bootstrap values (>70\%) based on 1000 replicates were shown at the branch nodes. Asterisks $\left(^{*}\right)$ indicate that the corresponding branches were also recovered in trees generated with the maximum parsimony and maximum likelihood methods. Bhargavaea cecembensis DSM 22132T was used as an out group. Bar, $1 \%$ substitutions per nucleotide position.

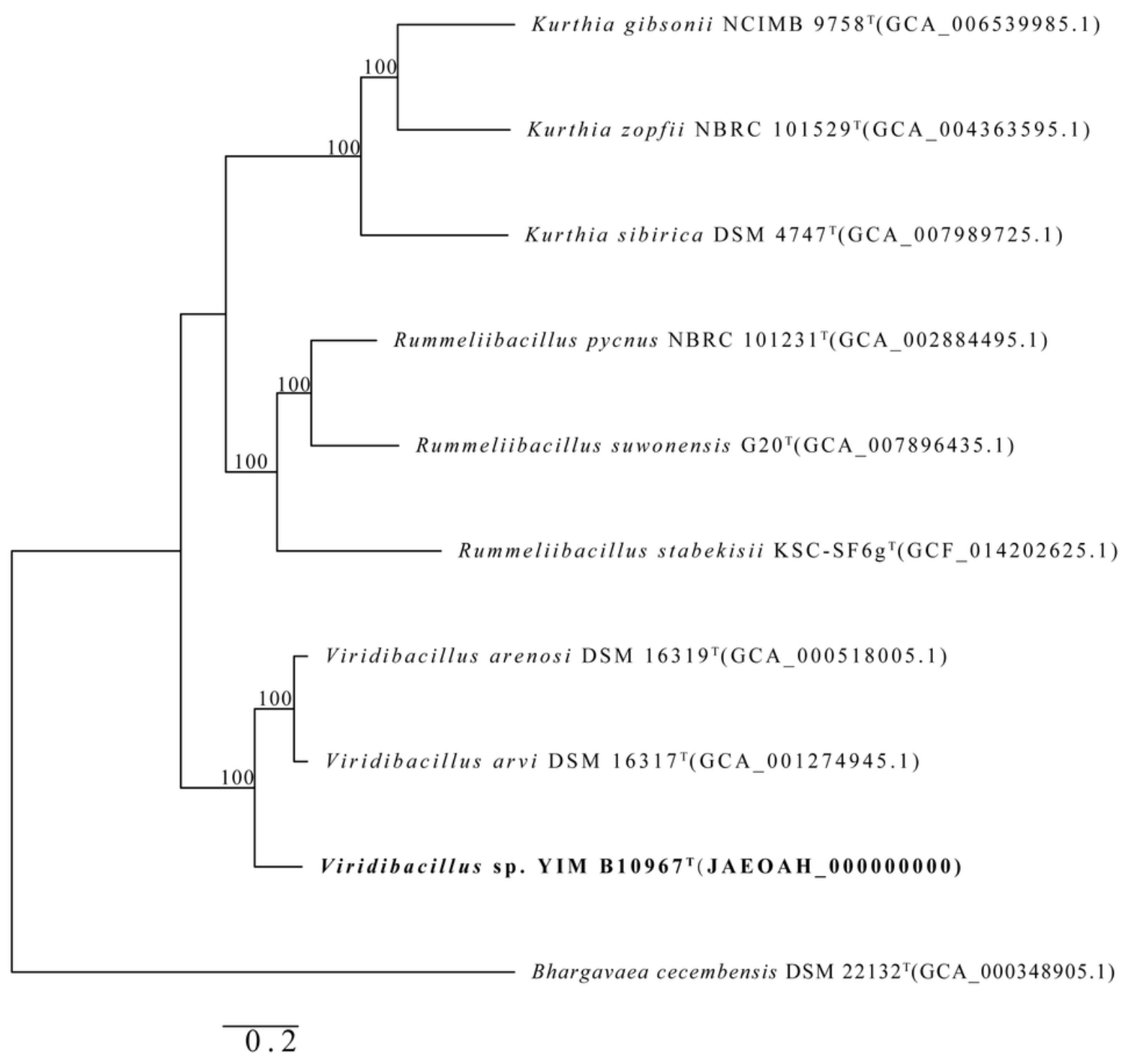

\section{Figure 2}

Phylogenomics tree of YIM B01967T with the closely related strains using the supermatrix method (containing 672 single-copy orthogroups, 171,059 genes). Bhargavaea cecembensis LMG 24411T was used as an out group. Bootstrap analysis was carried out using 100 replications. Percentage bootstrap values $(>70 \%)$ are given at branching points. 


\section{Supplementary Files}

This is a list of supplementary files associated with this preprint. Click to download.

- Supplementarymaterial.docx 